
Part of Journal of Research of the National Bureau of Standards, Volume 25,
October 1940

\title{
NOTE ON THE EFFECTS OF COBALT AND NICKEL IN STORAGE BATTERIES
}

\author{
By George W. Vinal, D. Norman Craig, and Clarence L. Snyder
}

\begin{abstract}
The presence of small amounts of cobalt or nickel sulfates in the electrolyte of storage batteries decreases the charging voltages. Iron sulfate was included in the study also, because of its chemical similarity to the others. As a result of 150 cycles of charge and discharge of a group of commercial storage batteries, it was found (1) that cobalt decreases the charging potential of positive plates but has a destructive action on the separators, (2) nickel decreases the charging potentials of negative plates without apparent harmful effect on the separators, and (3) iron has little if any effect on the potentials of either positive or negative plates. Advantages that might be gained by the use of cobalt, if the difficulty with separators is overcome, are indicated.
\end{abstract}

The cause of hydrogen evolution from storage batteries when not on charge was the subject of a paper by the authors ${ }^{1}$ several years ago. In that paper, as well as in other publications which are discussed there, it is evident that antimony liberated by corrosion of positive plates deposits on the negative plates and is a cause of local action which is accompanied by the liberation of gaseous hydrogen. The most obvious means of avoiding this would be the elimination of antimony from the battery, but no substitute for the lead-antimony alloy has found general use, although a number of substitute alloys have been proposed.

In general, lead alloys which are free from antimony result in charging voltages which are higher than those ordinarily observed. This fact has been cited by some engineers as the reason that substitute alloys often corrode more than the customary lead-antimony alloys. If the higher charging voltages were the cause of increased corrosion of the positive plates, the difficulty of finding a suitable substitute for lead-antimony alloys would be seriously increased. In the publication mentioned above, it was shown that the increased charging voltages in cells without antimony are caused by differences in the potentials of the negative plates, while the positive plate potentials remain substantially the same as in an ordinary cell. Positive grids without antimony, therefore, are not subject to more corroding conditions.

Other methods of attacking the problem of spontaneous hydrogen evolution include the search for a stable compound which would withstand cycling in a battery and yet inhibit the liberation of gaseous hydrogen when the battery is discharging or idle. Although

\footnotetext{
1 G. W. Vinal, D. N. Craig, and C. L. Snyder, BS J. Research 10, 795 (1933) RP567.
} 
a number of inhibitors have been tried, the results obtained at the Bureau up to the present time have not been particulariy successful. Search for a means of decreasing the charging potentials of the positive plates has been more encouraging, but much experimental work remains to be done. Our experiments were interrupted in July 1939. It seems worth while to make a preliminary report now, as the completion of the next phase of the work will require considerable time.

A paper ${ }^{2}$ entitled "The behavior of lead anodes in a sulfate electrolyte with particular reference to the influence of cobalt salts"

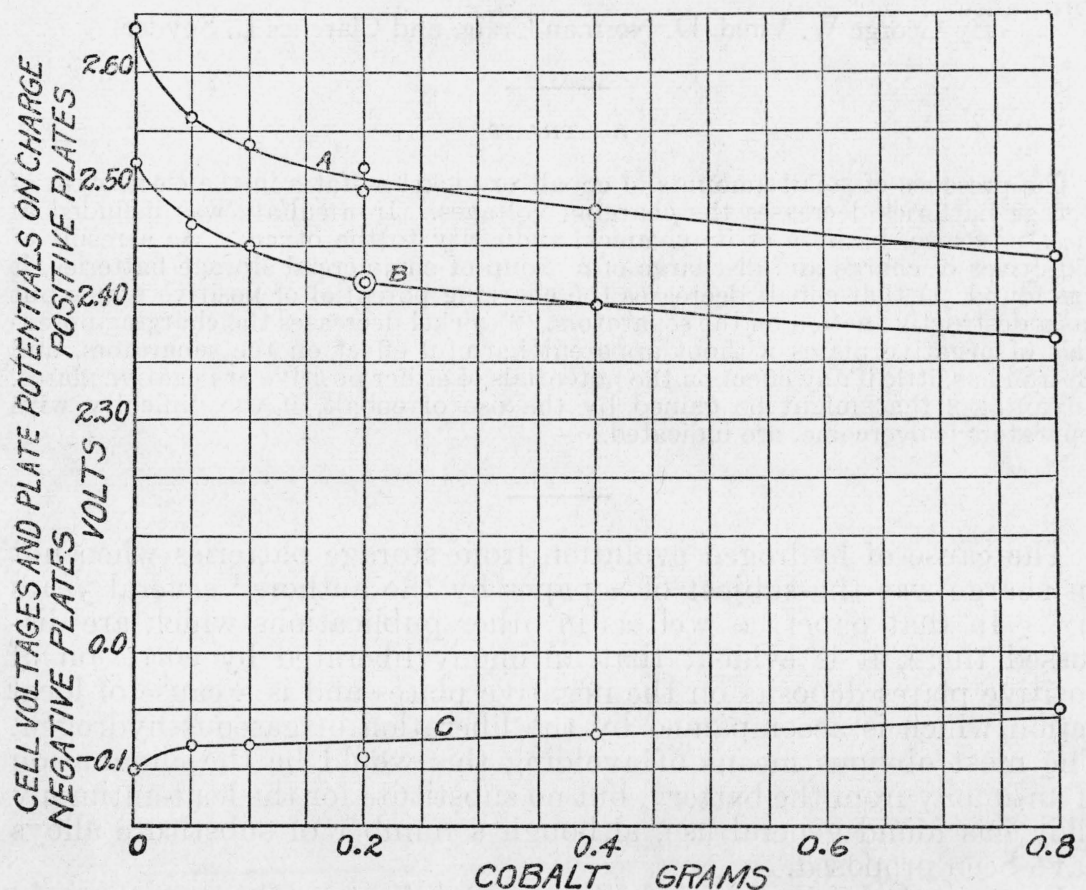

FIGURE 1.-Effect of cobalt on the cell voliage and on the cadmium potentials of the positive and negative plates.

Curve $A$, cell voltage; curve $B$, positive-plate potential; curve $C$, negative-plate potential

reports decreased corrosion of lead anodes when a cobalt salt is present. This paper is not concerned with storage batteries, and no potential measurements on positive plates are given. A paper by Fink ${ }^{3}$ discusses the catalytic properties of cobalt.

In our study of the effect of cobalt in a storage battery, various amounts of cobalt sulfate were added to the electrolyte. Previous experiments had shown that nickel also had an effect on charging voltages. Because of the relationship of iron to nickel and cobalt, all three of these were tested similarly. Comparisons were made with other cells to which none of these materials was added.

The experiments consisted in cycling small storage cells of the automotive type. These were of commercial manufacture. Each cell had a rated capacity of 45 ampere-hours and contained nine plates with wood separators. These cells were presumed to be sufficiently alike for the purposes of the experiment. In all, about 150

${ }^{2}$ M. Rey, P. Coheur, and H. Herbiet, Trans. Electrochem. Soc. 73, 315 (1938).

3 C. G. Fink, Trans. Electrochem. Soc. 71, 491 (1937). 
cycles of charge and discharge were made. Two discharges of 4 hours and two charges of 8 hours were made in each 24-hour period.

The results of the experiments are given in table 1 . The effect of cobalt in reducing the potential of the positive plates is shown in figure 1. The change in potential of these plates with increasing amounts of cobalt is large compared to the relatively insignificant changes that occurred in the potentials of negative plates. Cobalt, however, seriously affected the separators. In this respect it is like manganese, which affects both wood and rubber separators. It is probable that cobalt would affect rubber also. Some of the positive

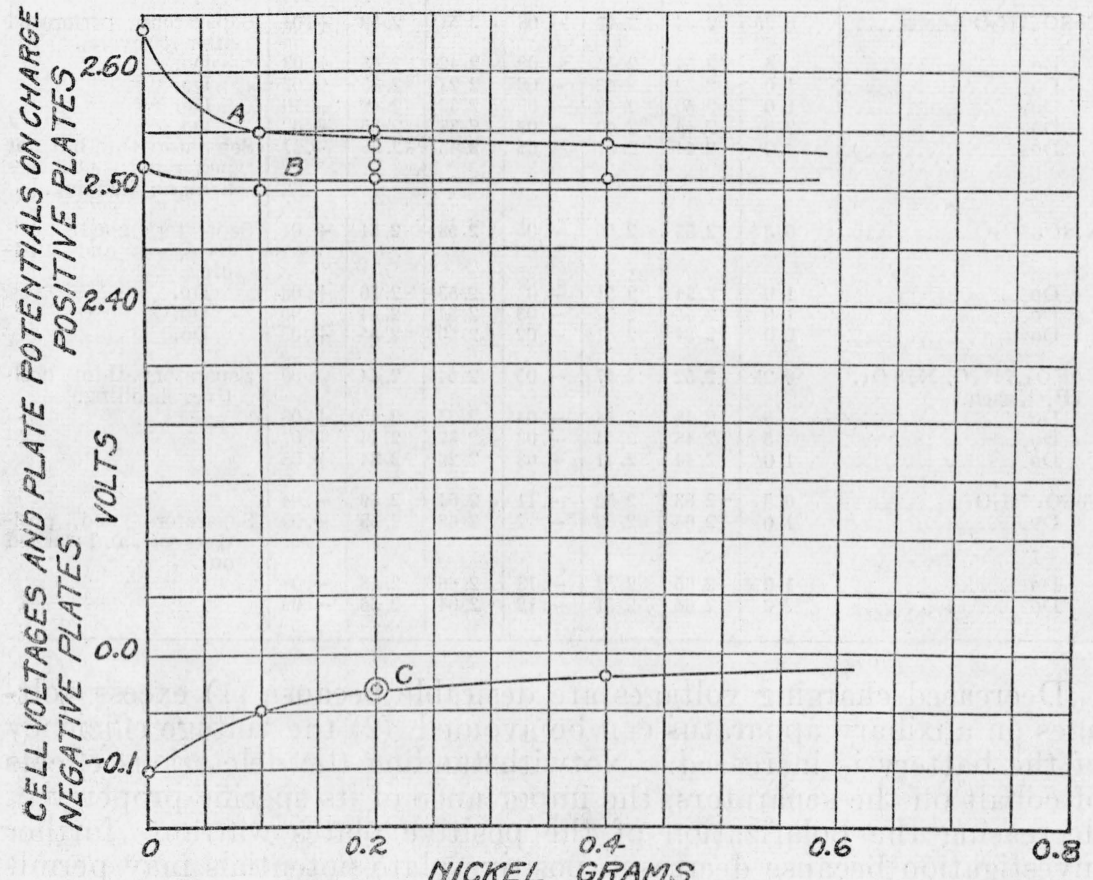

FIGURE 2.-Effect of nickel on the cell voltage and on the cadmium potentials of the positive and negative plates.

Curve $A$, cell voltage; curve $B$, positive-plate potential; curve $C$, negative-plate potential.

plates, particularly those in the cells having the highest amounts of cobalt, were in distinctly better condition at the end of the experiment than those in the blank cells.

Nickel affects the cadmium voltages of the negative plates and appears to be without specific action on the positives (see fig. 2). Separators in these cells were unaffected. When both cobalt and nickel were added to the cells, their effects were additive and independent of each other. The separators were, however, affected by the cobalt.

Iron has no specific effect on the potentials of either positive or negative plates. Its deleterious effects in storage batteries are well known and require no discussion here. 
TABLE 1.-Effect of materials added to the electrolyie

[Cobalt sulfate, $\mathrm{CoSO}_{4} .7 \mathrm{H}_{2} \mathrm{O}$; nickel sulfate, $\mathrm{NiSO}_{4} .7 \mathrm{H}_{2} \mathrm{O}$; ferrous sulfate, $\mathrm{FeSO}_{4} .7 \mathrm{H}_{2} \mathrm{O}$ ]

\begin{tabular}{|c|c|c|c|c|c|c|c|c|}
\hline \multicolumn{2}{|l|}{ Material } & \multicolumn{3}{|c|}{$\begin{array}{l}\text { Voltages, initial } \\
\text { tests }\end{array}$} & \multicolumn{3}{|c|}{$\begin{array}{l}\text { Voltages, after } 150 \\
\text { cycles }\end{array}$} & \multirow{2}{*}{ Remarks } \\
\hline Name & $\begin{array}{l}\text { Amount } \\
\text { added }\end{array}$ & Cell & $(+) \mathrm{Cd}$ & $(-) \mathrm{Cd}$ & Cell & $(+) \mathrm{Cd}$ & $(-) \mathrm{Cd}$ & \\
\hline None... & $g$ & $\stackrel{v}{v .64}$ & 2.52 & -0.11 & ${ }_{2}^{v} 62$ & 2.57 & $\begin{array}{c}v \\
-0.4\end{array}$ & $\begin{array}{l}\text { Mean of } 10 \text { control cells; } \\
\text { positives soft; some } \\
\text { shedding. }\end{array}$ \\
\hline $\mathrm{CoSO}_{4} .7 \mathrm{H}_{2} \mathrm{O}$ & 0.25 & 2. 56 & 2.47 & -.08 & 2. 51 & 2.52 & +.01 & Separators perforated \\
\hline 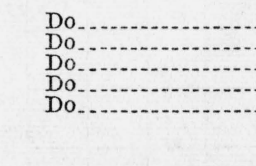 & $\begin{array}{l}.5 \\
1.0 \\
1.0 \\
2.0 \\
4.0\end{array}$ & $\begin{array}{l}2.54 \\
2.52 \\
2.50 \\
2.48 \\
2.44\end{array}$ & $\begin{array}{l}2.45 \\
2.42 \\
2.42 \\
2.40 \\
2.37\end{array}$ & $\begin{array}{l}-.08 \\
-.08 \\
-.09 \\
-.07 \\
-.05\end{array}$ & $\begin{array}{l}2.42 \\
2.27 \\
2.32 \\
2.33 \\
2.45\end{array}$ & $\begin{array}{l}2.45 \\
2.35 \\
2.42 \\
2.36 \\
2.38\end{array}$ & $\begin{array}{l}+.03 \\
+.07 \\
+.10 \\
+.02 \\
+.07\end{array}$ & $\begin{array}{l}\text { Do. } \\
\text { Do. } \\
\text { Do. } \\
\text { Do. } \\
\text { Separators thin but not } \\
\text { perforated; positives } \\
\text { firm; no shedding. }\end{array}$ \\
\hline 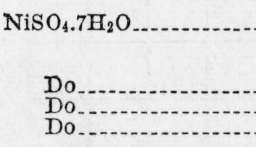 & $\begin{array}{l}1.0 \\
1.0 \\
2.0\end{array}$ & $\begin{array}{l}\text { 2. } 54 \\
2.55 \\
2.54\end{array}$ & $\begin{array}{l}2.51 \\
2.52 \\
2.51\end{array}$ & $\begin{array}{l}-.05 \\
-.03 \\
-.03 \\
-.02\end{array}$ & $\begin{array}{l}2.53 \\
2.54 \\
2.50\end{array}$ & $\begin{array}{l}2.54 \\
\\
2.56 \\
2.54 \\
2.55\end{array}$ & $\begin{array}{l}+.01 \\
+.03 \\
.00 \\
+.05\end{array}$ & $\begin{array}{l}\text { Separators good; posi-- } \\
\text { tives soft and shed- } \\
\text { ding. } \\
\text { Do. } \\
\text { Do. } \\
\text { Do. }\end{array}$ \\
\hline $\begin{array}{l}\mathrm{CoSO}_{4} .7 \mathrm{H}_{2} \mathrm{O}, \mathrm{NiSO}_{4} \text {. } \\
7 \mathrm{H}_{2} \mathrm{O} \text {, each. } \\
\text { Do } \\
\text { Do } \\
\text { Do }\end{array}$ & $\begin{array}{r}0.25 \\
.5 \\
.5 \\
1.0\end{array}$ & $\begin{array}{l}2.52 \\
2.48 \\
2.48 \\
2.44\end{array}$ & $\begin{array}{l}2.47 \\
2.44 \\
2.44 \\
2.41\end{array}$ & $\begin{array}{l}-.05 \\
-.04 \\
-.03 \\
-.03\end{array}$ & $\begin{array}{l}2.54 \\
2.35 \\
2.37 \\
2.26\end{array}$ & $\begin{array}{l}2.54 \\
2.42 \\
2.44 \\
2.34\end{array}$ & $\begin{array}{r}.00 \\
+.08 \\
+.07 \\
+.08\end{array}$ & $\begin{array}{l}\text { Separators thin; posi- } \\
\text { tives shedding. }\end{array}$ \\
\hline $\begin{array}{l}\mathrm{FeSO}_{4} .7 \mathrm{H}_{2} \mathrm{O} \\
\quad \mathrm{Do}\end{array}$ & $\begin{array}{l}0.5 \\
1.0\end{array}$ & $\begin{array}{l}2.63 \\
2.64\end{array}$ & $\begin{array}{l}2.52 \\
2.52\end{array}$ & $\begin{array}{l}-.11 \\
-.12 \\
-.13 \\
-.12\end{array}$ & $\begin{array}{l}2.64 \\
2.68\end{array}$ & $\begin{array}{l}2.59 \\
2.59\end{array}$ & $\begin{array}{l}-.04 \\
-.09 \\
-.08 \\
-.09\end{array}$ & $\begin{array}{l}\text { Separators good, posi- } \\
\text { tives soft, and washed } \\
\text { out. }\end{array}$ \\
\hline
\end{tabular}

Decreased charging voltages are desirable because (1) excess voltages on auxiliary apparatus can be avoided, (2) the voltage efficiency of the battery is increased. Notwithstanding the deleterious effects of cobalt on the separators, the importance of its specific property of decreasing the polarization of the positive plates warrants further investigation because decreased positive plate potentials may permit the use of lead alloys other than those containing antimony. The remaining problem is the protection of the separators. It may be possible to overcome this difficulty by the use of glass mats, but our experiments up to the present have not included this phase of the work.

In conclusion, the three related elements, iron, cobalt, and nickel, produce markedly different effects in a storage battery. Cobalt reduces the polarization of the positive plates, and nickel reduces the polarization of the negative plates. Iron, on the other hand, does not appear to affect the potential of either positives or negatives by a significant amount. Cobalt apparently decreased the corrosion of the positives but had a deleterious action on the separators.

Washington, July 31, 1940. 